This chapter appeared in an edited collection entitled

“Assault, strangulation and murder - challenging the sexual libido consent defence narrative",

in A. Reed \& M. Bohlander with N. Wake \& E. Smith (eds), Consent: Domestic and Comparative Perspectives (Abingdon: Routledge, 2016), ch.6. ISBN: 978-1-4724-6995-3.

This is the pre publication version of that article

\title{
ASSAULT, STRANGULATION AND MURDER - CHALLENGING THE SEXUAL LIBIDO CONSENT DEFENCE NARRATIVE
}

\section{Susan Edwards}

There may be deeper affinities than we as yet understand between the 'total freedom' of the uncensored erotic imagination and the total freedom of the sadist. That these two freedoms have emerged in close historical proximity may not be a co incidence. Both are exercised at the expense of someone else's humanity.' George Steiner Language and Silence (Faber 2010 edition) 114.

\section{Introduction}

In this chapter my intention is to explore the way in which the narratives of sexual libido and desire have informed the consent 'defence' in cases of non-fatal and fatal assault and more recently especially where strangulation is the method of violence used. The criminal law has long time established that consent, for whatever reason, including circumstances of private sexual conduct, cannot provide a defence to assault or murder. However, there are cases where the defendant who charged with murder alleges that the deceased 'victim' consented to the activity which formed part of the sexual encounter which led to death and in consequence he should not be criminally liable for murder. The criminal law has permitted exceptions to the general rule that consent cannot be a defence to physical harm. These exceptions have 
been driven by social policy but are restricted to, for example, particular contact sports, including boxing. ${ }^{1}$

The question which forms the discussion in this chapter is the place, if any, of consent as a defence or in mitigation in regulating harms that follow sexual acts between two or more allegedly consenting parties when followed by non-fatal or fatal harm. In this chapter I explore the manipulation by the defendant of a sexual consent narrative in assault and fatal assault and especially where women who die at the hands of men are strangled and asphyxiated. Whilst bondage, domination, sadism and masochism (BDSM) contenders argue that there should be a legal space for sexual violence in the sexual encounter ${ }^{2}$ and that partners who engage in sexual acts, including erotic asphyxia, do so from true consent and choice, the concern is that the defence contention that the victim /deceased consented to the violent acts in such cases is a claim that cannot be tested by the courts. The BDSM narrative is being appropriated by defendants to disguise what is essentially cruel and misogynist conduct as a strategy to manipulate trial and sentencing outcomes. Whilst there are instances where single men ${ }^{3}$ have died following auto-erotic asphyxia the death of women in heterosexual relationships is particularly worrying because of the prevalence of strangulation as a specific form of violence against women in both non fatal and fatal assault.

\footnotetext{
${ }^{1}$ See R v Brown [1993] 2 All ER 75 [HL]; R v Brown [1994] 1 AC 212.

${ }^{2}$ See for example, The Spanner Trust, (an organisation set up to lobby for change to the law on consensual S/M activity) <http://www.spannertrust.org/ >accessed 12 October 2015.

${ }^{3}$ See Michael Hutchence (1997)

$<$ http://news.bbc.co.uk/onthisday/hi/dates/stories/november/22/newsid 4006000/4006205.stm. > accessed 12

October 2015; See David Carradine reported by Brian Orloff, 'David Carradine Died of Accidental Asphyxiation' (July 2 2009) People; See also Roger Byard, Steven Hucker, and Robert Hazelwood, (1990) 'A comparison of typical death scene features in cases of fatal male and female autoerotic asphyxia'. Forensic Science International, 48, 113-121.
} 


\section{Regulating Harms}

The underlying principle or norm that has regulated this area of human conduct relies on the harm justification for intervention in the private sphere. Here the Millsean tenet has prevailed, in so far as it is generally agreed that the law has no proper place in the regulation of human conduct unless it can be established that harm to others is occasioned. J.S. Mill in his essay On Liberty ${ }^{4}$ stated as follows:

The only freedom which deserves the name, is that of pursuing our own good in our own way, so long as we do not attempt to deprive others of theirs, or impede their efforts to obtain it. Each is the proper guardian of his own health, whether bodily, or mental and spiritual. (...) The only purpose for which power can be rightfully exercised over any member of a civilized community, against his will, is to prevent harm to others. His own good, either physical or moral, is not a sufficient warrant. ${ }^{5}$

Within the criminal law where individual harm is caused to another the motive of sexual libido within a consensual practice has never constituted a sufficient public policy reason to provide an exception to the general rule. What is significant however is the changing landscape with regard to both the appearance of and shift in perception of this sexual narrative. Narratives of consent to sexual harms including bondage, domination, sadism and masochism (BDSM), conduct which Foucault refers to as 'spirals of power and pleasure, ${ }^{6}$ once regarded almost universally as expressions of sexual perversion and cruelty, ${ }^{7}$

\footnotetext{
${ }^{4}$ John Mill, Essay on Liberty (Shields C 1958) 1st Edition 1859.

5 ibid 16, 68.

${ }^{6}$ Michael Foucault, The History of Sexuality vol 1 (Pantheon Books 1978).

${ }^{7}$ Richard von Krafft Ebing, Psychopathia Sexualis (Rebman London 1901).
} 
are practices now described by some as 'transgressive sexuality'. These narratives of BDSM are entering the criminal law with greater frequency as part of defence submissions and considered by judges in trial and appellate courts where arguments of consent to BDSM are being presented as part of a defence or in mitigation of sentence. The case of $R v$ Brown ${ }^{8}$ and $R v$ Coutts $^{9}$ (in England and Wales) are two cases where the defendants case at trial relied on arguments of sexual consent to BDSM. In Brown, the House of Lords importantly ruled that consent could not establish a defence to assault and in Coutts the jury rejected the defendant's case that death by asphyxia was an accident and the sexual activity causing it consensual. The case of Brown involved a number of homosexual men who engaged in harming each other as part of the sexual activity between them, including genital torture to the buttocks, anus, penis, testicles and nipples including wounding and branding. The defendants were charged and convicted (notwithstanding their alleged consent) of assault occasioning actual bodily harm (Offences against the Person Act 1861, s47) and grievous bodily harm (Offences against the Person Act 1861, s 20). Whilst the practices were deliberate the prosecution no doubt concluded that proving intention might be difficult since the primary objective of the defendants was to heighten sexual excitement and to satisfy a sado-masochistic libido not to harm per se.

In Coutts the victim died in the course of strangulation, choking and asphyxia. Such harm said the defendant was agreed to by the victim to increase her sexual arousal. The defendant's account did not convince the jury and a verdict of guilty to murder was returned at trial and also on a retrial.

\section{Sexualising Harm}

\footnotetext{
${ }^{8}$ Brown (n 1).

${ }^{9} R v$ Coutts [2006] UKHL 39; [2007] 1 Cr App R 6.
} 
Evidence of bondage, domination, sadism and masochism in sexual conduct has been long established in authoritative works for example of Krafft-Ebing, ${ }^{10}$ Havelock Ellis ${ }^{11}$ and Montgomery Hyde. ${ }^{12}$ The philosophical writings of Nietzsche ${ }^{13}$ have also been pre-occupied with sadism and cruelty, ${ }^{14}$ as have the pornographic novels and plays of de Sade. ${ }^{15}$ These several discourses have been detailed and critiqued in the writings for example of Georges Bataille, ${ }^{16}$ Michel Foucault, ${ }^{17}$ and Gilles Deleuze. ${ }^{18}$ Angela Carter ${ }^{19}$ in her critique of De Sade explores how these narratives are culturally determined and how a male dominated society produces a pornography of universal female acquiescence. BDSM practises considered peccadillos throughout the late twentieth century ${ }^{20}$ are being positioned by some as sexual lifestyle choices. Anne McClintock points out that these practices are both theatre and part of the social subculture of fetishism. ${ }^{21}$ A report in 1990 conducted by the Kinsey Institute found that 5-10\% of the U.S. population 'engages in sadomasochism for sexual

\footnotetext{
${ }^{10}$ Richard von Krafft Ebing, (n 7;. See also Richard von Krafft Ebing, Psychopathia Sexualis (Wet Angel Books; Revised edition 2006); See also Anne McClintock, 'Maid to Order Commercial Fetishism and gender power' in Social Text (ed) Anne McClintock (Duke University Press 1993) 87-116 at 89.

${ }^{11}$ Havelock Ellis, Studies in the Psychology of Sex vols 1-7. (F.A.Davis and Company 1930).

${ }^{12}$ Montgomery Hyde, A History of Pornography (A Four Square Book 1966).

${ }^{13}$ Friedrick Nietzsche, The Will to Power (Weidenfeld and Nicholson 1968).

${ }^{14}$ See Jonathan Glover, Humanity A Moral History of the Twentieth Century (Yale University Press 2012$) 11$.

${ }^{15}$ For example see Donatien Alphonse François de Sade, Juliette (Grove Press 1968) (originally published 1757).

${ }^{16}$ Georges Bataille, Visions of Excess Selected Writings 1927-1939 (University of Minnesota 1985).

17 ibid M. Foucault (n 6).

${ }^{18}$ Giles Delueze Masochism: Coldness and Cruelty \& Venus in Furs (Zone Books 1989).

${ }^{19}$ Angela Carter, The Sadeian Woman (Virago 1979) 20.

${ }^{20}$ See Stephen Marcus, The Other Victorians (Corgi 1969).

${ }^{21}$ ibid McClintock (n 10).
} 
pleasure on at least an occasional basis, with most incidents being either mild or stage activities involving no real pain or violence. ${ }^{, 22}$

Yet the risks and dangers of these practices cannot be ignored. BDSM in massage parlours and as part of sexual services ${ }^{23}$ was a concern of the Policy Advisory Committee (The Criminal Law Revision Committee, Prostitution: Off Street Activities 1985 ${ }^{24}$ ). On men leaving sado-masochistic premises the committee reported:

[t]he nuisance to the public involved men being seen leaving the premises showing obvious signs of injury or distress, behaving indecently, vomiting in the vicinity and depositing offensive litter (such as soiled and bloodstained linen) in nearby litter bins (...) the men who visit such places do so with the deliberate purpose of subjecting themselves to torture, humiliation and pain.

Despite the fact that the experience of those working in 'sexual services' point to the fact that it is men who desire sadism, the feminist writings of Andrea Dworkin ${ }^{25}$ have consistently argued that these sadistic practices are a patriarchal atrocity against women. Reichian analysis would argue that sadism is part of the attitude of men and the product of destroyed sexuality. ${ }^{26}$

Sadomasochism 'theatre', 'freedom' or violence has been aided and facilitated by pornographic scenarios which rely for the most part on narratives of violence and sadism, masochism and cruelty.

\footnotetext{
${ }^{22}$ June Reinisch and Ruth Beasley, Kinsey New Report on Sex (St. Martin’s Press 1990) 162 - 3.

${ }^{23}$ See Susan Edwards 'Selling the Body, Keeping the Soul: Sexuality, Power, the Theories of Prostitution' in Sue Scott and David Morgan (ed) Body Matters (The Falmer Press 1993) 89; See also the Cynthia Payne Trial in Gloria Walker and Lynn Daly Sexplicitly Yours: The Trial of Cynthia Payne (Penguin 1987) 66; See also Claude Jaget (ed) Prostitutes: Our Life (Falling Wall Press 1980) 105-108.

24 The Criminal Law Revision Committee, Prostitution: Off Street Activities 19859688 para 3.8, 161.

${ }^{25}$ Andrea Dworkin, Pornography men possessing women (The Women's Press 1981).

${ }^{26}$ Wilheim Reich, The Invasion of a Compulsory Sex Morality (Condor 1972).
} 
Such realities and representations have invaded the mainstream and become part of the genre of commercial 'fiction, ${ }^{27}$ media and 'entertainment.' For example in 1992 Madonna sings and performs in the music video for the film 'Die another Day' ${ }^{28}$ title track. Madonna is clad in a tight fitting vest, her breasts and nipples protruding, she is bruised, writhing and sexualized. Her torturers submerge her head in a tank of water before they strap her down in an electric chair. This torture is routinely practiced on men and women in dictatorships as Glover ${ }^{29}$ details. This format of representation with its fusion of violence and sex, so redolent of Sade's work, typifies the violent pornographic genre. It is conceived of and produced to entertain. Of course, Madonna, magically escapes. As we all know in the real world of torture escape is pure fiction. Nonetheless Jenny Colgan writing in the $\operatorname{Scotsman}^{30}$ asks:

Have you seen the Madonna video for the Die another Day theme song? It's fabulous. She's great in it, playing both her evil twin and someone about to get killed on an electric chair. She's sexy, she looks terrific and she brings real drama to what is, in the end, just a promotional video.

Amnesty International documents the reality - such captives do not escape, nor are they set free. They disappear and die. As Dworkin recognized there is no atrocity in war that the pornographers have not based their scenarios upon. ${ }^{31}$ Certainly the BDSM narrative of domination, subjugation and infliction of harm is a redolent feature of patriarchy. The sadomasochism narrative has historically fixed women as masochistic enjoying and desiring subjugation. Andrea Dworkin identified this habituated trope in the heterosexual pornographic

\footnotetext{
${ }^{27}$ E.L.James, (Erika Mitchell) Fifty Shades of Grey (Vintage 2011).

$28<$ https://www.youtube.com/watch?v=BfvD_brrrTc> accessed October 21915.

${ }^{29}$ ibid Jonathan Glover (n 14) 11.

${ }^{30}$ November 19, 2002.

${ }^{31}$ ibid Andrea Dworkin (n 25) 144
} 
scenario observing that 'male orgasm is linked to inequality. ${ }^{32}$ The tropes of women as masochistic, as Andrea Dworkin has argued, rely on the representation that 'Whatever you do to her she will enjoy it. ${ }^{33}$ Kathleen Barry ${ }^{34}$ warns that sadomasochism is forcing a woman against her will.

Criminal law encounters the sadist perpetrator who commits violence upon both an unwillingly victim and on the victim he describes as willing. The question for the criminal law is whether consent to such activity can ever be a relevant consideration. ${ }^{35}$ Some would claim that where BSDM is part of consensual sexual activity it should not be interfered with. Disturbingly such arguments are found in defence submissions. Such representations operate within a sexual space that is still unequal. Male sexual violence against women has often been presented in the legal narrative as an equal playing field i.e. as 'rough sex' or 'vigorous sexual activity' (Slingsby below). This has harmed women making them responsible for their own demise. 'Part of the feminist legal theory project must include inquiry into how legal

\footnotetext{
32 Andrea Dworkin, Omnibus 'Pornography 1991'< https://www.youtube.com/watch?v=L9j7-zZks08> accessed 31 October 2015; See also Andrea Dworkin, 'Against the Male Flood: Censorship, Pornography, and Equality 8 Harv. Women's L.J. 1 (1985) 26; See also <http://pzacad.pitzer.edu/ mma/teaching/MS110/reading/feminism\&pornography_pp19-38_94-120.pdf > accessed 13 October 2015.

33 ibid Dworkin (n 25).

${ }^{34}$ Kathleen Barry, Female Sexual Slavery (New York University Press 1979) 209.

${ }^{35}$ Igor Primoratz, Sexual Morality: Is Consent Enough?Ethical Theory and Moral PracticeVolume 4, Issue 3, 201-218.
} 
reasoning transforms the embodied imaginings from male lives into the "objective" form of doctrine which passes for the "normative.", 36

\section{The Criminal Law}

The question of whether a consent to non-fatal assault (excluding rape) within a sexual context vitiates a charge of assault has been considered by the criminal courts for several decades, and the subject of consideration by trial and appellate judges in England and Wales including Anglo-American jurisdictions ${ }^{37}$ in recent years. The law in England and Wales, the US and Canada is unequivocal, consent is not defence to sado-masochistic assault.

Whilst consent is no defence, in 2013, at a trial at Ipswich Crown Court a 'not guilty' verdict was returned in the trial of Steven Lock $^{38}$ who was charged with assault causing actual bodily harm. He had begun a relationship with a female complainant which included sado-masochistic role play. He went on to abuse her beyond the limits to which she had consented. She suffered bruising to the buttocks and neck.He chained her 'like a dog' to his bedroom floor and whipped her repeatedly with a rope. He said that she had consented. He said in his evidence that he had got the idea from Fifty Shades of Grey. ${ }^{39}$ In Canada, in $R v$ $J . A(2011)^{40}$ the defendant (JA) claimed that the complainant (KD) had agreed to being choked. After being choked JD lost consciousness and the defendant committed sexual acts upon her. When she regained consciousness she found that her hands were tied behind her

\footnotetext{
36 Judith E.Grbich, 'The Body in Legal Theory' (eds) M.A.Fineman, N.S. Thomadsen, At the Boundaries of Law: Feminism and Legal Theory. Volume 1 (Routledge 1991).

${ }^{37}$ See Jian Ghomeshi case < http://www.independent.co.uk/news/people/jian-ghomeshi-accused-of-newphysical-and-sexual-abuse-allegations-9828378.html> accessed 2 November 2015.

${ }^{38}$ Independent.co.uk (22 January 2013).

${ }^{39}$ E.L.James, (Erika Mitchell) Ibid (n 27).

${ }^{40}$ R v J.A (2011) 2 SCR 440; 2011 SCC 28 (CanLII).
} 
back and JA was inserting a dildo into her anus. KD made a complaint to the police two months later. In her statement she said that she had consented to the choking but not to the sexual activity that had occurred when she lost consciousness. As she was in a custody dispute with JA over their son she felt pressured to withdraw the original allegation. However the case went to trial and JA was subsequently convicted of sexual assault. He appealed. The appeal court, by a majority, allowed the appeal and set aside the conviction. On appeal to the Supreme Court of Canada the court ruled that consent in advance cannot be given concluding that, 'Parliament viewed consent as the conscious agreement of the complainant to engage in every sexual act in a particular encounter. ${ }^{41}$ In the US in People v Jovanovic (2000), ${ }^{42}$ a doctoral student engaged in Internet discussion of BDSM interests with a female student (Rzucek). They arranged to meet for a meal and then went back to his apartment. The complainant alleged that 'Jovanovic tied her up, violently raped and sodomized her, struck her repeatedly with a club, burned her with candle wax, and repeatedly gagged her with a variety of materials. ${ }^{43}$ She was bitten and had an object inserted into her rectum. After 20 hours she managed to escape and went to the police. She said in her evidence that they had agreed on a safe word which she would say when she wanted it to stop but Jovanovic ignored her pleas. Her screams could be heard by others within the vicinity. Jovanovic was found guilty of assault, sexual assault and kidnapping and sentenced to fifteen years to life in prison. The Court of Appeals, (the majority concurring) reversed all the convictions ordering a new trial on evidentiary grounds that the trial judge had erred in invoking the rape-shield

\footnotetext{
41 ibid (McLachlin).

${ }^{42}$ People v Jovanovic, 95 N.Y.2d 846 (2000).

${ }^{43}$ Dr. Oliver Jovanovic, Plaintiff, v. The City Of New York, Detective Milton Bonilla, Shield No. 61,Iindividually And in his official capacity, New York County Assistant District Attorney Linda Fairstein, Individually and in her official capacity, Defendants. No. 04 Civ. 8437(PAC).Sept. 28, 2010. 2010 WL 8500283.
} 
law, denying the jury access to evidence regarding Rzucek's interest in sadomasochistic activity. The Court of Appeals said that, consent, while available as a defence to the charges of kidnapping and sexual assault, was irrelevant to the assault charge. Jovanovic refused to plead guilty to a misdemeanor and charges were subsequently dropped against him.

\section{England and Wales - The case law history}

Probably one of the earliest reported trials in England and Wales involving Sadomasochism was that of $R v$ Donovan $(1934)^{44}$ this is suggested by the fact that counsel in legal argument did not refer to any similar cases as authority so we can assume that the matter had not previously been adduced before the criminal courts. In this case, the defendant had induced a young woman of seventeen to accompany him to his garage where he beat her with a cane 'in circumstances of indecency (...) It appeared that the appellant was addicted to a form of sexual perversion. ${ }^{45} \mathrm{He}$ was found guilty of both indecent assault and common assault and sentenced to eighteen months imprisonment. He appealed on several grounds, inter alia, that consent provided a defence to a charge of indecent assault. The Crown in its submission contended that flagellation for the purpose of sexual gratification cannot provide a defence to indecent assault. The Crown's case was that she had gone with the defendant because 'she was compelled or induced by fear to do so. ${ }^{46}$ (It is of note that the language used in this case formed part of the ruling in $R v$ Olugboja ${ }^{47}$ The Court of Appeal when considering consent

\footnotetext{
${ }^{44} R v$ Donovan [1934] 2 KB 498; see also for commentary Lorena Leigh Sado-Masochism, Consent, and the Reform of the Criminal Law The Modern Law Review, Vol. 39, No. 2 (1976) 130-146.

45 ibid 502.

46 ibid 503.

${ }^{47} R v$ Olugboja [1982] QB 320.
} 
in 1934 was well aware that if consent was induced by fear then it was not freely given. Such reasoning later formed the basis of s 74 of the Sexual Offences Act 2003). The defendant's case was that she went with him willingly. Medical evidence reported seven or eight marks on her body and concluded that she had sustained a 'fairly severe beating.' The Court of Appeal (quashed the conviction on the basis of a misdirection) and ruled that violence even if with consent for the purposes of sexual gratification is unlawful.

The consent narrative in BDSM surfaced again in later decades. In empirical research I conducted on rape trials in 1980 in the London, Manchester and Birmingham courts, in one particular case where two brothers were charged with rape and the complainant had suffered bruising to the face and lip, the defence submission was that the victim had been asked to be hit, saying 'hit me hit me I'm kinky. ${ }^{48}$ The question of whether consent to violence in the course of sexual activity could negate a charge of assault was considered authoritatively by the House of Lords (HL) in the case of $R v$ Brown, ${ }^{49}$ Lords Templeman, Jauncey and Lowry (affirming) and Lords Mustill, and Slynn (dissenting).The HL considered whether sadomasochism fell into a special category of acts, like duelling and prize fighting and whether restricting the general principle of consent as a defence under these circumstances was in the public interest. The trial judge, Judge Rant at the Central Criminal Court asserted:

This is not a witch-hunt against homosexuals (...) nor is it a campaign to curtail the private sexual activities of citizens of this country. Much has been said about individual liberty and the rights people have to do what they want with their own bodies but the courts must draw the line between what is acceptable in a civilised society and what is not.

\footnotetext{
${ }^{48}$ Susan Edwards, Female Sexuality and The Law (Martin Robertson Oxford 1981) 166 nb 23.

${ }^{49} R v$ Brown (n 1).
} 
The appellants' case was that over a 10-year period they had willingly participated in sexual violence. These acts of violence were committed to film and it was the discovery of the film that led to the subsequent police investigation. Neither the Court of Appeal, nor the House of Lords viewed the videotapes. Lord Mustill said 'the House has been spared'. Lord Templeman reasoned that there was a difference between incidental violence and violence inflicted for the indulgence of cruelty: 'I am not prepared to invent a defence of consent for sado-masochistic encounters which breed and glorify cruelty and result in offences. ${ }^{50}$ Lord Lowry was of the opinion that sado-masochistic homosexual activity cannot be regarded as conducive to the enhancement or enjoyment of family life or conducive to the welfare of society. The courts could not give these activities a 'judicial imprimatur'. Lord Jauncey asserted, ' $(\ldots)$ there is nothing in ss 20 and 47 to suggest that consent is either an essential ingredient of the offences or a defence thereto'. ${ }^{51}$ It was not, he said, in the public interest. Lord Mustill considered at length judicial analyses of the relationship between violence and consent in a range of diverse human conduct, from prize-fighting and sparring, Coney $(1882)^{52}$ Young $(1866)^{53}$ Orton $(1878)^{54}$ to ice hockey Ciccarelli (1989) $)^{55}$ and the chastisement of children, to beatings inflicted with a cane for the benefit of the aggressor's sexual gratification Donovan (1934). ${ }^{56}$ The HL decision resulted in criticism from

\footnotetext{
${ }^{50} R$ v Brown (n 1) 84.

${ }^{51} R v$ Brown (n 1). 91.

${ }^{52} R v$ Coney (1882) 8 QBD 534.

${ }^{53} R v$ Young (1866) 10 Cox CC 371.

${ }^{54} R$ v Orton (1878) 39 LT 293.

${ }^{55} R v$ Ciccarelli (1989) 54 CCC (3d) 121 (Canada).

${ }^{56} R v$ Donovan (n 44) 498.
} 
campaigning groups and also from within academia. ${ }^{57}$ It is no less significant here in a discussion of the risk of violence to female partners in heterosexual sexual violence since significantly the men when subjected to the harm and the maiming's and torture were placed in a situation characteristic of womanhood.

There were further criminal cases where the act of violence against a complainant was presented as part of consensual erotic sex between equals. In Boyea $(1992)^{58}$ the defendant was convicted of indecent assault. He had inserted part of his hand into the complainant's vagina causing her bodily harm. She said she passed out after the incident. The extent of the violence inflicted went far beyond the risk of minor injury to which, if she did consent, her consent would have been a defence. The Court of Appeal granted an appeal against a six year sentence of imprisonment reducing the term to four years. In this case although consent was not raised by the defence, the judge in his summing up raised it, as did the Court of Appeal. The trial judge said this:

In some cases where an indecent assault is alleged whether the person complaining of the assault consented to what was done becomes a crucial issue in the case because in many cases where an indecent assault is alleged consent to what was done by the person complaining of the assault is a complete defence. In a case where consent is a complete defence to the charge it is for the prosecution

\footnotetext{
${ }^{57}$ Nicholas Bamforth, 'Sadomasochism and Consent' [1994] Crim L R 661 [663]; Sharon Cowan, 'The Pain of Pleasure: Consent and the Criminalisation of Sado-Masochistic 'Assaults' in Andrew Ashworth and Eric M. Clive Essays in Criminal Law in honour of Sir Gerald Gordon (Edinburgh Studies in Law) (English University Press 2010) [133; Matthew Weait and Rosemary Hunter, 'Commentary' on ' $R v$ Brown' in Rosemary Hunter, Claire McGlynn and Erika Rackley (eds) Feminist Judgments: From Theory to Practice (Hart Publishing 2010) [252]; Marianne Giles, ' $R$ v Brown Consensual Harm in the Public Interest' (1994) 57 Modern Law Review 101, 104.

58 R Boyea [1992] Crim LR 574.
} 
to satisfy the jury that the person complaining of the indecent assault did not consent; it is not for the defence to prove that there was consent by the complainant..$^{59}$

More significantly perhaps were the remarks of the Court of Appeal:

[t]he court must take into account that social attitudes have changed, particularly in the field of sexual relations between adults. As a generality, the level of vigour in sexual congress which was generally acceptable, and therefore the voluntarily accepted risk of incurring some injury was probably higher now than it was in $1934 .^{60}$

The Court of Appeal went on, 'Moreover, it was inconceivable that she would have consented to the injuries which were in fact inflicted on her. ${ }^{61}$

$R v$ Wilson (1996) ${ }^{62}$ involved a consensual act of the branding of a husband's initials on the buttocks of his wife with a hot knife. The defence in a spectacular demonstration of the power of the performative utterance ${ }^{63}$ said it amounted to no more than 'personal adornment.' It was held not to be an offence since it did not amount to s 47 Offences Against the Person Act 1861. The court not wishing to interfere between husband and wife accepted defence argument that this act was very different from Brown amounting only to branding. The Court of Appeal said 'We share the judge's disquiet that the prosecuting authority thought it fit to bring these proceedings. ${ }^{64}$ In $R v$ Emmett (1999) ${ }^{65}$ the complainant's head was covered with

\footnotetext{
${ }^{59}$ Reported in Susan Edwards Sex and Gender in the Legal Process (Blackstone Press 1996) 353.

60 ibid 353.

61 ibid 353.

${ }^{62} R v$ Wilson [1996] 3 WLR 125.

${ }^{63}$ John L.Austin How to do things with words (Cambridge, MA: Harvard University Press 1962).

${ }^{64} R v$ Wilson (n 62) 128E.
} 
a plastic bag tied at the neck with a ligature whilst the defendant engaged in oral sex with her. The complainant was deprived of oxygen to the brain and sustained subconjunctival haemorrhages in both eyes and petechial bruising to the neck. The defendant also poured lighter fuel on her breasts and set it alight such that she lost consciousness and suffered burns which later became infected. The defendant was sentenced to 9 months' imprisonment on each count consecutive, the sentence being suspended for 2 years. It was held that consent was no defence and his appeal dismissed. In $R v$ Meachen, ${ }^{66}$ in an attempt to bolster a claim that his violence and her injury was consensual the defendant in his evidence said 'you enjoyed yourself didn't you.' The complainant suffered injuries to her rectum and lower bowel during an assault when she was unconscious following having consumed alcohol and being drugged with a rape date drug, GHB. The injury was so severe that a colostomy was performed and the complainant was fitted with a colostomy bag. The defendant, who claimed the victim consented, was convicted of grievous bodily harm with intent and sentenced to ten years imprisonment upheld on appeal.

The 'vigorous sexual activity' narrative frequently used to rebut allegations of rape ${ }^{67}$ is also used to normalise violence. In the case of Slingsby $(1995)^{68}$ the victim died of septicaemia. The appellant had sexual intercourse with her, buggered her, and penetrated her vagina and anus with his ringed hand inflicting the injuries from which she died. The Crown alleged that the defendant was guilty of manslaughter; although the prosecution accepted that the activity, if consensual, would not amount to an assault or any other crime. It was held that consent to injury did not arise because all they were considering at the time was 'vigorous

\footnotetext{
${ }^{65} R$ v Emmett (1999) (unreported, 18 June 1999), CA, No. 9901191/ZZ, 1999); The Times (15 October 1999).

${ }^{66} R v$ Meachen (2006) Court of Appeal (Criminal Division) [2006] EWCA Crim 2414.

${ }^{67} R v$ Sampson [2001] EWCA Crim 154.

${ }^{68} R v$ Slingsby (1995)Crim LR 570.
} 
sexual activity.' The judge ruled that the defendant could not be found guilty since 'fisting' was not an unlawful or dangerous act! On this ruling the Crown offered no evidence and the judge entered a verdict of not guilty. Of course the Court was not able to hear the victim's evidence. Section 2 Sexual Offences Act 2003 creates an offence of penetration where the complainant does not consent and fisting would fall within that section.

\section{Dead and Asphyxiated}

In several cases where women die following strangulation the defence argument is either that both parties engaged in erotic asphyxia to which the deceased had consented or else strangulation or pressure to the neck was part of the accused's 'love making' or 'sexual embrace' and that what had occurred was a tragic accident. Since strangulation is a common method of killing a female partner ${ }^{69}$ the argument that the deceased engaged in erotic asphyxiation and therefore consented to the strangulation is an allegation easily made and difficult to refute. Considering strangulation and asphyxiation as a method of killing, from 1987-2006 $(\mathrm{n}=1960)^{70}$ of women partners killed, 28 per cent of female partners were strangled or asphyxiated. More recent statistics for $2012-2013^{71}$ and $2013-2014,{ }^{72}$ similarly

\footnotetext{
${ }^{69}$ See Susan Edwards, Policing Domestic Violence (Sage, 1989);Susan Edwards, Sex and Gender in the Legal Process (Blackstone Press, 1996) 368-370; Susan Edwards, ‘Ascribing Intention - The Neglected Role Of Modus Operandi - Implications For Gender' Contemporary Issues in Law (1999/2000) vol 4 iss 3 235-256; Susan Edwards, 'Abolishing Provocation and Reframing Self Defence - The Law Commission options for Reform' [2004] Crim. L.R. 181; Susan Edwards, 'Descent into Murder: Provocation's Stricture-The Prognosis for Women Who Kill Men Who Abuse Them' (2007) Journal of Criminal Law 71 (342); Susan Edwards, 'Anger and Fear as Justifiable Preludes for Loss of Self-Control' (2010) Journal of Criminal Law 74 (223). 70 The data set under analysis supplied to me by the Home Office Statistical Department with kind permission. ${ }^{71}$ Office for National Statistics <http://www.ons.gov.uk/ons/rel/crime-stats/crime-statistics/focus-on-violentcrime-and-sexual-offences--2012-13/rpt---chapter-2---homicide.html?format=print>\#tab-Method-of-Killing > 14 accessed 23 July 2015.
} 
show that when men killed female partners/ex-partners, in 27 per cent and 24 per cent respectively, strangulation ${ }^{73}$ is the killing method. In some cases there is evidence of the reliance on erotic asphyxia as part of part of a defence strategy. However, the frequency of the use of erotic asphyxia as a defence and in mitigation in trials for murder is unknown since it is only when such cases are appealed that such details are reported. Furthermore, there may be some cases where erotic asphyxia is alleged which do not proceed to trial. To illustrate this possibility Milroy and Beckman ${ }^{74}$ reported a case of same sex erotic asphyxia which although proceeded to the trial stage was discontinued prior to the jury hearing the evidence. In this particular case two men were engaging in intercourse during the course of which the older partner requested that his neck be squeezed, the pressure applied by his partner occurred over a period of approximately two minutes. The body of the man being squeezed suddenly went limp. His partner attempted resuscitation but this was unsuccessful. The Crown had to decide whether to prosecute on the basis of unlawful act manslaughter or on the basis of gross negligence. The prosecution decided to proceed on the grounds that the behaviour of the defendant amounted to gross negligence. The case was not in the end put before the jury, the judge accepting that there was no case to answer.

Of cases that do go to trial the difficulty of contesting a defence submission which relies on accident following erotic asphyxia is illustrated in the following cases. One of the

\footnotetext{
${ }^{72}$ See Office for National Statistics Chapter Two Violent Crime and Sexual Offences Homicide ONS date 12 February 2015 <http://www.ons.gov.uk/ons/dcp171776_394478.pdf>13-14; See also Focus on Partner/ ex partner Homicide http://www.ons.gov.uk/ons/rel/crime-stats/crime-statistics/focus-on-violent-crime-and-sexualoffences--2012-13/rpt---chapter-2---homicide.html?format=print>\#tab-Focus-on-Partner-Ex-Partner-Homicides $>$ accessed 23 July 2015.

${ }^{73}$ See Office for National Statistics Chapter Two Violent Crime and Sexual Offences Homicide ONS <http://www.ons.gov.uk/ons/dcp171776_352260.pdf > 14 accessed 23 July 2015.

${ }^{74}$ Christopher Milroy MD and Michael Beckman QC Murder, manslaughter or nothing - 147 NLJ 1736
} 
earliest reported cases of erotic asphyxiation was that of $R v$ Sharmpal Singh [1962]. ${ }^{75}$ Here, the accused killed his wife while she was in bed. The defence called no evidence at the trial but made an unsworn statement stating that on the night in question he had intercourse with his wife he pressed on her neck and throat and chest during what was described as a 'sexual embrace.' '(...) their Lordships of the Board understood that expression to mean no more than that the handling of the throat and the pressure on the chest were part of the love-making or bodily movements that went with the sexual act. ${ }^{76}$ At the end of the case the trial judge said this:

Whether it was during intercourse or whilst Ajeet was just lying in her bed, to strangle one's wife is murder, be it to stifle her complaints because she objects to intercourse, or refuses to submit to it, or even, she having consented to intercourse, the accused strangled her to gratify his lust.

Counsel for the appellant argued that a verdict of manslaughter should not be returned unless it is proved that the accused knowingly acted with reckless disregard for his wife's safety. The Court said, 'It is possible that, as the Court of Appeal thought, the accused was "applying pressure in an excess of sadism to frighten or torment her, or to overcome resistance.",77 The appeal was dismissed and manslaughter upheld.

Of cases that do go to trial the difficulty of contesting a defence which relies on the defence of consensual erotic asphyxia is illustrated in the following cases. In $\mathrm{R} v$ Williamson (1994), ${ }^{78}$ a defence of manslaughter was accepted by the Crown. The defendant's case was

\footnotetext{
${ }^{75} R v$ Sharmpal Singh [1962] 2 WLR 238.

76 ibid 241.

77 ibid 245.

${ }^{78} R v$ Williamson (1994) 15 Cr App R (S) 364,365; Regina $v$ Williamson (1993) Times, 19 October; See also Edwards (n 69) 393, 413.
} 
that he and the deceased had engaged in mutual partial asphyxiation in order to heighten sexual arousal. Neck compression, he said, was part of their sexual activity which he described as 'pseudo-masochistic. ${ }^{79} \mathrm{He}$ had also smothered his girlfriend with a pillow because, he said, to quieten the noise she made during intercourse. A sentence of four years was reduced to three on appeal. The Crown's pathologist stated that the cause of death was asphyxia. The pathologist said that sexual practices involving mutual asphyxiation were recognised in the medical profession as being practised and as being highly dangerous and a number of deaths had occurred during such activity. Dr. Paul on behalf of the defence expressed the same view. On appeal it was submitted that the defendant and the deceased 'had been deeply attached to each other'. Significantly perhaps, the appellant had a number of previous convictions including convictions for violence: assaults on the police; wounding with intent; common assault; and assault occasioning actual bodily harm. The appeal court issued a note of warning, 'Anyone indulging in that form of conduct that thereby causes a death will be very likely to receive a substantial sentence of imprisonment in the future' ${ }^{80}$ Williamson as it turned out was a very dangerous man and especially a high risk to women. Following his release he went on to abuse other women and to kill his mother. ${ }^{81}$ In Niall Duncan Mcdonald against Her Majesty's Advocate $(2004)^{82}$ the appellant was charged with murdering his wife. The defendant's case was that the incident had begun as a consensual sexual encounter. He said:

At this point my arms were round Mandy's throat because that's the way we normally love sort of thing (...) then, I am not sure of the time span, maybe two minutes,

\footnotetext{
${ }^{79}$ Susan Edwards (n 69) 365.

${ }^{80}$ Susan Edwards (n 69) 367

${ }^{81}$ Susan Edwards (n 69) 354.

${ }^{82}$ Niall Duncan Mcdonald against Her Majesty's Advocate [2004] S.C.C.R. 161.
} 
Mandy's noises stopped (...) I withdrew the whip and realised Mandy wasn't moving I might have slapped her face to try and get her round. At that point I tried to give her the, the kiss of eh, life. There was nothing. ${ }^{83}$

The defendant appealed and the appeal court finding no fault with the judge's ruling upheld the appeal against conviction. ${ }^{84}$ In $R v$ McCarry and Waters (2009), ${ }^{85}$ manual and ligature strangulation resulted in death. McCarry's case was that asphyxia was consensual to increase the deceased's sexual pleasure ${ }^{86}$ and death was an accident. The Crown was permitted to adduce evidence of McCarry's non-sexual violence, including strangulation, towards former sexual partners as bad character evidence. This was said to be admissible under section 101(1)(d) of the 2003 Act on the ground that it was relevant to an important issue between the defendant and the prosecution. ${ }^{87}$ The prosecution established that in fact McCarry had a long history of strangling women during sexual intercourse ${ }^{88}$ and a propensity to strangle women. ${ }^{89}$ His grounds for appeal against a conviction for murder were refused. In Sacket

\footnotetext{
${ }^{83}$ ibid.

${ }^{84}$ HM Advocate $v$ Rutherford [1947] JC 1.HC the accused was charged with murdering a woman by strangling her. He stated in evidence that:'she had repeatedly asked him to strangle her to death', that he had put his necktie round her neck and that he had pulled it and pulled it again on her telling him to get on with it.

${ }^{85}$ Robert George McCarry, Paul Waters [2009] EWCA Crim 1718; Toby William Norris [2004] EWCA Crim 2800.

${ }^{86}$ ibid [6] [11] [36] [37].

${ }^{87}$ ibid [31[. (They were each sentenced to life imprisonment for the murder and to other concurrent terms of imprisonment for the other offences. Upon an Attorney General's reference, this court increased the recommended minimum periods before release from the life imprisonment to 24 years for McCarry and 18 years for Waters.)

${ }^{88}$ ibid [16].

${ }^{89}$ ibid [20].
} 
(2012) ${ }^{90}$ the appellant killed his girlfriend by manual and ligature strangulation holding her in a headlock and strangling her possibly with her thong. The defence claim was that the defendant had been 'play- fighting'. The judge considered the seriousness as 'particularly high' and a 25 year minimum term was handed down and upheld on appeal.

\section{Contesting the Sexual Pleasure Misogynist Strangulation Representation}

The danger of this misogynist narrative ${ }^{91}$ to women as a group is all too apparent from the above cases. Luce Irigaray argues that in sexuality the reality is that woman is an 'obliging prop for the enactment of mans' fantasies ${ }^{92}$ The erotic asphyxiation narrative is a redolent feature in pornographic representation and its availability and legality was challenged following the killing by Graham Coutts of Jane Longhurst. In $R v$ Coutts, ${ }^{93}$ Graham Coutts was the partner of the girlfriend of the deceased. On 14 March 2003, Jane Longhurst was strangled to death by him. Her body was found 'with a ligature made from a pair of tights tied twice around the neck, with a knot on the right-hand side. ${ }^{94}$ The expert pathologist(s) for the prosecution and the defence agreed that the cause of death was compression of the neck by a ligature, causing asphyxiation. The prosecution expert considered vascular strangulation or respiratory strangulation the most likely mechanisms causing death within about two to three minutes, considering vagal inhibition to be less likely. By contrast, the defence expert considered vagal inhibition the most likely explanation death occurring possibly within one to two seconds. The expert opinion was instructive in buttressing the competing claims of

\footnotetext{
${ }^{90} R v$ Sacket [2012] EWCA Crim 3229.

${ }^{91}$ See Jane Caputi, The Age of Sex Crime (The Women's Press 1988); Deborah Cameron and Elizabeth Frazer The Lust to Kill (Polity 1987).

${ }^{92}$ Luce Irigaray, This Sex which is not one (Ithaca 1986) 25

${ }^{93} R v$ Coutts (n 9).

${ }^{94} R v$ Coutts (n 9) [3].
} 
murder and manslaughter, respectively adduced. In his defence, Coutts claimed that the deceased had engaged in consensual erotic asphyxial sex and death an accident:

He had put his hand around her neck, and she had squeezed his hand to tighten his grip. He had then, with her consent, tied a pair of tights round her neck and tied a knot in them. At some point he had closed his eyes and released the tights. He did not know how the deceased had died. ${ }^{95}$

The case for the Crown was that he had murdered the deceased in order to obtain sexual gratification. Evidence was adduced that he was in the habit of visiting websites which related to sex and violence containing images of asphyxiation, strangulation, rape, torture and violent sex and that the day before the deceased's death he had logged on to a website 'Death by asphyxia' for approximately an hour and three quarters. For the Crown it was disclosed during the trial that Coutts was in fact a habitual strangler having strangled (none fatally) several of his partners during the course of sexual activity with them. One former girlfriend said that he 'placed his hand around her neck, before and during intercourse, and had used tights and knickers around her neck. ${ }^{96}$ Another said that he had tied a stocking around her neck during intercourse. His current partner said he had indulged in what he called 'breathe control play.' Coutts himself said he had been 'fascinated' by women's necks for about 20 years. The jury did not accept his defence that the victim had consented and returned a verdict of murder. He appealed on the grounds that the he had been denied the opportunity of an alternate verdict. The House of Lords agreed on the opportunity of an alternate verdict which was put before them as a point of law of public importance and a retrial was ordered. At retrial, he was convicted of murder and sentenced to a 26 year minimum term. Coutts' interest in strangulation instigated law reform regarding the possession of extreme violent

\footnotetext{
${ }^{95} R v$ Coutts (n 9).

96 ibid.
} 
pornography. Following agitation for reform, s 63 of the Criminal Justice and Immigration Act $2008^{97}$ was introduced making it illegal to possess 'an extreme pornographic image'98 which included 'an act that threatens a person's life,' punishable with up to three years in prison.The Criminal Justice and Immigration Act 2008 was preceded by a Consultation Paper in 2005 on Possession of Extreme Pornography, proposing four new offences which became law. However, the provisions fell short of what the campaigners had intended leaving scenes of rape relatively untouched by legislation. In fact, since 2002 the film industry was left relatively unfettered and the British Board of Film Classification (BBFC)'s trend of licensing

\footnotetext{
97 'An image is 'extreme' if it falls within Criminal Justice and Immigration Act 2008 s. 63(7) and is “grossly offensive, disgusting or otherwise of an obscene character" (s. 63(6)):Section 63(7) of the Criminal Justice and Immigration Act 2008states that an image falls within that subsection if it: portrays, in an explicit and realistic
} way any of the following--(a) an act which threatens a person's life,(b) an act which results, or is likely to result, in serious injury to a person's anus, breasts or genitals,(c) an act which involves sexual interference with a human corpse, or (d) a person performing an act of intercourse or oral sex with an animal (whether dead or alive).'

${ }^{98}$ Criminal Justice and Immigration Act 2008 Subsections (2) to (8) set out the definition of "extreme pornographic image". In order to be considered pornographic, an image must be of such a nature that it must reasonably be assumed to have been produced solely or mainly for the purpose of sexual arousal. Whether this threshold has been met will be an issue for a jury to determine. Subsection (6): An extreme image is one which is grossly offensive, disgusting or otherwise of an obscene character and which depicts one of a list of acts set out in subsection (7). These are explicit and realistic portrayals of: acts which threaten a person's life; this could include depictions of hanging, suffocation, or sexual assault involving a threat with a weapon; acts which result in, or are likely to result in, serious injury to a person's anus, breasts or genitals; this could include the insertion of sharp objects or the mutilation of breasts or genitals; acts which involve sexual interference with a human corpse; or a person performing an act of intercourse or oral sex with an animal. The people and the animals portrayed must appear to a reasonable person to be real. 
films for R18 certification consolidated their approach of non-interference. 'Irreversible' - a film with a nine minute rape scene was granted a certificate in March 2003. When the film was shown in Cannes, 250 people walked out. The position of the BBFC was that a shocking or unpleasant viewing experience provided the violence did not suggest that the victim enjoyed it or deserved it is not sufficient grounds in the UK for censorship of material intended for adult consumption. So where does the BBFC stand on gratuitous violence. It seems to rely for its non-interference on the belief that people will find it shocking that is on 'the aversion effect' which was indeed the very same belief turned into a defence argument which saved the publishers of otherwise pornographic material from being convicted under the Obscene Publication Act 1959. The United States, Meese Commission in their review of pornography in 1986 reached this conclusion. 'Substantial exposure to sexually violent materials as described here bears a causal relationship to anti-social acts of sexual violence and, for some sub-groups, possibly to unlawful acts of sexual violence. ${ }^{99}$

The objective of s 63 Criminal Justice and Immigration Act 2008 was to bring to justice those who possessed 'extreme pornographic images' which also included sexually violent assault and strangulation. Yet any examination of the reported case law reveals that the cases reaching the appeal courts involve sex with animals which commentators have argued was not an act that threatens a person's life - the primary purpose of the section. ${ }^{100}$ Indeed since 2011 my own perusal of prosecutions under s 63 of the Criminal Justice and

\footnotetext{
${ }^{99}$ Report of the Commission on Obscenity and Pornography Meese Report, 1986 U.S. Attorney General's Commission on Pornography Vol 1325.

${ }^{100}$ Susan Easton, 'Criminalising the possession of extreme pornography: sword or shield'? Journal of Criminal Law 2011; See also Andrew D. Murray, 'The Reclassification of Extreme Pornographic Images' The Modern Law Review, Vol. 72, No. 1 (2009) 73-90; Imogen Jones, ‘A Beastly Provision: Why the Offence of “Intercourse with an Animal” Must Be Butchered’ The Journal of Criminal Law, December 2011 75: 528-544.
} 
Immigration Act 2008 reveals that they continue to be brought in connection with child pornography and/or bestiality. ${ }^{101}$ The new provision continued to fail to give effect to what was intended and scenes of rape and violence against women and strangulation were not brought before the courts. This lacunae has been partly addressed with regard to rape as pornography by the introduction of s 37 of the Criminal Justice and Courts Act 2015, amending s 63 Criminal Justice and Immigration Act 2008 to prohibit the possession of an extreme pornographic image if it portrays, in an explicit and realistic way, either of the following — 'the non-consensual penetration of a person's vagina, anus or mouth by another with the other person's penis, or by another with a part of the other person's body or anything else, and a reasonable person looking at the image would think that the persons were real'. However even within this amendment the sexualisation of strangulation remains absent. Of course it could be argued that such imagery could fall into s 63 (7) of the Criminal Justice and Immigration Act 2008 'an act that threatens a persons' life. However such representations are yet to come before the courts to be tested.

${ }^{101}$ See for example $R v$ M.H; $R v$ Ping Chen Cheung, $R v$ Smith, [2013] EWCA Crim 167; $R v$ Williamson [2011] EWCA Crim 2002; $R v$ Wilde (Nicholas John) [2010] EWCA Crim 1985; AG's Reference No. 70 of $2012, R v$ Daffin [2012] EWCA Crim 3119; R v Lewis (Simon Richard) ([2012] EWCA Crim 1978; $R$ v Oliver (Phillip)[2011] EWCA Crim 3114; $R$ v Filor (David John) [2012] EWCA Crim 2788; $R$ v Wilkins (Paul) [2012] EWCA Crim 1653, $R v$ Edwards (Neil) [2012] EWCA Crim 1263; $R$ v Wakeling (Derek Arnold) [2010] EWCA Crim 2210; $R$ v Sinclair (Stephen) (2010)[2010] EWCA Crim 175; $R$ v L (A) [2013] EWCA Crim 215; $R$ v Clark (Oliver) [2012] EWCA Crim 1707; $R$ v Hathaway (Brian David) [2012] EWCA Crim 825; $R$ v David Robert Reed Twist [2012] EWCA Crim 760 . 
What needs to be done is a recognition of the dangers in the BDSM narrative and the dangers of asphyxiation. Web sites and pornographic images need to be challenged in the courts. ${ }^{102}$

The prosecution need to fully implement s 21 Offences Against the Person Act 1861 which provides:

Whosoever shall, by any means whatsoever, attempt to choke, suffocate, or strangle any other person, or shall by any means calculated to choke, suffocate, or strangle, attempt to render any other person insensible, unconscious, or incapable of resistance, with intent in any of such cases thereby to enable himself or any other person to commit, or with intent in any of such cases thereby to assist any other person in committing, any indictable offence, shall be guilty of felony, and being convicted thereof shall be liable (...) to be kept in penal servitude for life.

Notwithstanding, strangulation has rarely formed part of an indictment. ${ }^{103}$ Where the BDSM narrative may persuade juries to return not guilty verdicts as was the case in Stephen Lock (above), or else where a victim is killed and a manslaughter verdict returned then judges have discretion in sentencing as in Sacket (above). The Criminal Justice Act 2003 s 143(1) provides, 'the court must consider the offender's culpability in committing the offence and any harm which the offence caused, was intended to cause or might foreseeably have caused.' The first consideration is the gravity of the actus reus expressed in 'any harm.' The second consideration provides for a number of states of mind in setting out degrees of culpability from the lower threshold of 'might foreseeably' right up to the threshold of just below legal

\footnotetext{
${ }^{102}$ I ask why this site has not been banned <http://www.dangerandplay.com/2011/12/26/how-to-choke-awoman/ >accessed 9 November 2015.

${ }^{103}$ See $R$ v Moura [2009] EWCA Crim 1891.
} 
intention. This provision was considered in Ellerbeck. ${ }^{104}$ where the defendant had strangled his wife killing her (although he did not rely on erotic asphyxia).The Court of Appeal refused an appeal against an eight year sentence concluding that the potential for injury is plain handing down a very important judgment with regard to strangulation:[13] (...) the judge, also in passing sentence, made the point, at $\mathrm{p} 6$, that on an objective assessment of the facts, the potential for serious injury to be caused by what the Appellant did is plain. This is important because remarks of that sort properly reflect s 143 in directing attention to the consequences and to the potential harm which was risked by manual strangulation of the wife's neck.

Other jurisdictions, including Canada and some US states ${ }^{105}$ have criminalised strangulation in itself regardless of its part in the commission of other crimes. The jurisdiction of England and Wales might consider doing likewise. It is regrettable that the Law Commission in its Report 'Offences Against the Person'106 does not consider this problem of strangulation.

Male violence against women and the ubiquity of grabbing a partner's neck must always be very carefully scrutinised. As to the question of erotic asphyxia there is no evidence that it heightens women's sexual libido but there is evidence that men routinely use strangulation as a method of assault, that it is a trope and a reality in pornography, that women die in the course of it and that it is part of the misogyny narratives. Andrea Dworkin recognised that women die in the course of the debate some would like to have.

\footnotetext{
${ }^{104} R v$ Ellerbeck [2010] EWCA Crim 905.

${ }^{105}$ In the US, most federal states have made strangulation a specific felony, and increased sentencing. See <http://www.ndaa.org/ncpa_state_statutes.html > accessed May 4, 2015.For a comprehensive overview of all US states measures.

${ }^{106}$ Law Com No 361 Reform of Offences Against the Person November 2015.
} 
"This is an Accepted Manuscript of a book chapter published by Routledge/CRC Press in Consent: Domestic and Comparative Perspectives, 2016, available online:

https://www.routledge.com/Consent-Domestic-and-Comparative-Perspectives/Reed-BohlanderWake-Smith/p/book/9781472469953 